\title{
Engaging Undergraduate Students in Research Activities: Are Research Universities Doing a Better Job?
}

\author{
Shouping Hu • George D. Kuh • Joy Gaston Gayles
}

(C) Springer Science+Business Media, LLC 2007

\begin{abstract}
Engaging undergraduate students in research activities has been advocated as an innovative strategy to improve American higher education (Boyer Commission, Reinventing undergraduate education: A blueprint for America's research universities. The Carnegie Foundation for the Advancement of Teaching, Stony Brook, NY, 1998). This study compared the frequency of undergraduate student research experiences at different types of colleges and universities from the early 1990s through 2004. The results indicate that the frequency of student research experiences increased since 1998 at all types of institutions and that students at research universities were not more likely than their counterparts elsewhere to have such experiences. The findings were consistent across major fields. To live up to their claims, research universities must find additional ways to involve undergraduates in research with faculty members.
\end{abstract}

Key words undergraduate research $\cdot$ student engagement $\cdot$ research university $\cdot$ higher education reform

Concerns about the quality of undergraduate education have generated calls for reform in American higher education (Association of American Colleges and Universities 2002,

Shouping Hu is Associate Professor of Higher Education at Florida State University. He received his M.S. degree in Economics and Ph.D. in Higher Education from Indiana University. His research and scholarship focuses on postsecondary access and persistence, college student experience, and higher education finance.

George D. Kuh is Chancellor's Professor of Higher Education and Director of the Center for Postsecondary Research at Indiana University Bloomington. He received his Ph.D. degree from the University of Iowa. His research focuses on the quality of undergraduate education.

Joy Gaston Gayles is Associate Professor in Adult and Higher Education at North Carolina State University. She received her Bachelor's degree from Shaw University, Master's degree from Auburn University, and Ph.D. in Higher Education from The Ohio State University. Her research focuses on college student learning and development.

S. Hu $(\bowtie) \cdot$ G. D. Kuh · J. G. Gayles

Department of Educational Leadership and Policy Studies, College of Education,

Florida State University, 113 Stone Building, Tallahassee, FL 32306-4452, USA

e-mail: shu@coe.fsu.edu 
2007; National Commission on the Future of Higher Education 2006). In addition to knowledge acquisition, most observers contend that a high quality undergraduate experience should expose students to new ideas and ways of thinking and actively engage them in exploring and discovering new knowledge (Association of American Colleges and Universities 2002, 2007; Boyer Commission 1998; Council on Undergraduate Research 2003). Indeed, being involved in a research project as an undergraduate is associated with various desirable effects such as persistence, graduate school study, and future career choice (Pascarella and Terenzini 2005). Nagda et al. (1998) found that working on research with a faculty member contributed to student persistence at the University of Michigan. A subsequent study (Hathaway et al. 2002) suggested that participation in undergraduate research was also positively related to the probability of pursuing graduate education and conducting research in the future. Similarly, Nnadozie et al. (2001) reported findings that undergraduate research experiences were positively related to graduate school success.

These results are consistent with other research on the effects of research experiences on student development and satisfaction (Justice et al. 2007; Pascarella and Terenzini 2005; Volkwein and Carbone 1994). Pascarella and Terenzini (2005) suggested that undergraduate research programs offer the following:

...an amalgam of situational and behavioral factors intended both to provide a window on the intellectual life of the scholar and to promote students' active involvement in their own learning, increased and more meaningful interaction with faculty members, opportunities to apply course-related theory and skills in solving real problems, and a challenging intellectual activity. (p. 406)

Given their inquiry-intensive missions, research universities are thought to have a comparative advantage in terms of providing high quality research experiences for their undergraduates (Gonzalez 2001). Many research universities, including Duke, Michigan, Pennsylvania State University, and the Berkeley campus of the University of California, feature opportunities to work side by side with productive scholars on the cutting edge of their fields. For instance, the Duke University (2006) Undergraduate Bulletin states,

As a research university, Duke seeks to connect undergraduate education to the broad continuum of scholarship reflected in its faculty. Such a rich setting provides students with opportunities to become involved in a community of learning and to engage in the process of discovery and move beyond being the passive recipients of knowledge that is transmitted to being an active participant in the discovery, critical evaluation, and application of knowledge and understanding. (p. 25)

Whether research universities do, in fact, offer a comparative advantage in this arena has not been empirically verified. That is, do such promises actually materialize? How frequently do undergraduates at research universities actually work on research projects with a faculty member?

\section{Purpose of the Study}

This study examined undergraduate student experiences with research at different types of colleges and universities across different time periods. This examination enabled us to 
determine whether or not research universities do, indeed, offer a relative advantage in this aspect of undergraduate education. Three questions guided the research:

- How do undergraduates at research universities compare with their counterparts at other types of institutions in terms of the frequency of their research experiences?

- Has the frequency of undergraduates doing research with a faculty member at research universities increased since the Boyer Commission's call for reform in 1998?

- Because the nature of faculty work differs by both institutional type and discipline (Clark 1983), are there differences in the frequency with which students have research experiences across fields of study?

\section{Materials and Methods}

\section{Data Source and Instrument}

The data for this study are from the 3rd and 4th editions of the College Student Experiences Questionnaire (CSEQ) research program at the Indiana University Center for Postsecondary Research (Gonyea et al. 2003; Kuh et al. 1997). The CSEQ is designed for students attending four-year colleges and universities and gathers information about students' background and their experiences in three areas. The first area is the amount of studying, reading, and writing students do and the time and energy (effort) they devote to other educationally purposeful activities. The second area is student perceptions of the extent to which their institution's environment emphasizes important conditions for learning and personal development. The final area is composed of student self-reported estimates of how much they have gained from attending college in a range of areas considered as desirable outcomes of college. Based on their review of the major college student research instruments, Ewell and Jones (1996) concluded that the CSEQ has excellent psychometric properties and high to moderate potential for assessing student behavior associated with college outcomes. A recent comprehensive study suggested that student self-reported data on engagement in college activities can be used for institutional comparison (Kuh et al. 2006).

\section{Data and Variables}

This study used 47,646 students from 120 colleges and universities in the 1990-1997 databases and 36,830 students from 96 institutions in the 1999-2004 databases. Although we could have used the 2000 Carnegie classification for this study, we chose to use the 1994 classification for several reasons. First, the earlier versions of the Carnegie classification, including the 1994 version, have stronger emphasis on research activities, particularly those supported by federal government, for research universities (Carnegie Foundation for the Advancement of Teaching 1994; McCormick 2000). This emphasis may be more congruent with the topic of this study on student research experiences. Further, given the prominence of the Boyer Commission and the influence of their 1998 national report, in which the older version was used, it is important to see whether or not there has been improvement in student research experiences in colleges and universities. Therefore, we used the five categories of institutions from the 1994 classification: research universities, doctoral universities, comprehensive colleges and universities, selective liberal arts colleges, and general liberal arts colleges. Given that this study focused on undergraduate students in four-year 
institutions, the composition of institutions is generally comparable to the Carnegie distribution of different types of four-year institutions (McCormick 2000).

Two dependent variables are used in this study. The first one is the undergraduate research experience composite, a scale made up of student responses to four questions. These items include "worked with a faculty member on a research project," "discussed ideas for a term paper or other class project with a faculty member," "gone back to read a basic reference or document that other authors referred to," and "completed an experiment or project using scientific methods." Reliability coefficients for this scale in all samples are above 0.65 levels. The purpose of this scale is to cover more areas that are closely related to the development of research experiences and skills. The second one is the single item of "worked with a faculty member on a research project," an indicator that directly reflects undergraduate experiences in doing research work with faculty.

The independent variable in this study is institutional type according to the 1994 Carnegie classification of higher education institutions. Since both institutional and student characteristics can influence student experiences and outcomes (Pascarella and Terenzini 2005), we used the following control variables in this study: student gender, age, race/ ethnicity, year in college, major field of study, institutional control (public vs. private), and a measure of institutional selectivity from Barron's Profiles of American Colleges (2002). The control variables were coded as follows:

- $\operatorname{Sex}(0=$ women, $1=$ men $)$;

- Race or ethnicity was coded as a set of dummy variables: Asian Americans, African Americans, Latinos, Whites, and Other Ethnicity (Native American and others), with Whites as the omitted reference group;

- Year in college (first year, sophomore, junior, and senior, with first year omitted as reference group);

- Institutional control $(0=$ public, $1=$ private $)$;

- Institutional selectivity $(6=$ most competitive, $5=$ highly competitive, $4=$ very competitive, 3 =competitive, $2=$ less competitive, and $1=$ not competitive);

- Major field of study (four major field clusters coded as dummy variables: humanities (arts, literature, history, philosophy, religion, foreign language); science and mathematics including computer science; social sciences (economics, political science, psychology, sociology); and professional/applied (agriculture, business, education, engineering, and health-related fields such as nursing). Students who were undecided or indicated some "other" major were excluded from this analysis. Pre-professional was omitted as the reference group.

\section{Data Analysis}

First, we compared the mean values of student research experience measures in the five different types of institutions across the two time periods (1990-1997 and 1999-2004), using the research experience composite and the single-item student-faculty research indicator (Table I).

Second, we used multiple regressions to examine the relationships between institutional type, time period, and undergraduate research experiences (Ethington et al. 2002). We first conducted multiple regressions for the two dependent variables in two different time periods separately, using research universities as the reference group. Next we ran regressions for samples disaggregated by institutional type for the dependent variables across the two time periods, using the 1990-1997 time period as the reference group. 
Table I Descriptive Statistics of Undergraduate Research Experience Indicators

\begin{tabular}{|c|c|c|c|c|c|c|c|}
\hline & & \multicolumn{3}{|c|}{ Research Experience Composite } & \multicolumn{3}{|c|}{ Working with Faculty on Research } \\
\hline & & 1990-1997 & 1999-2004 & Difference & 1990-1997 & 1999-2004 & Difference \\
\hline \multirow[t]{6}{*}{ All } & RU & 6.703 & 7.723 & 1.020 & 1.228 & 1.445 & 0.217 \\
\hline & DU & 6.661 & 7.687 & 1.026 & 1.211 & 1.396 & 0.185 \\
\hline & $\mathrm{CCU}$ & 6.600 & 7.425 & 0.825 & 1.244 & 1.422 & 0.178 \\
\hline & SLA & 7.319 & 8.303 & 0.984 & 1.318 & 1.541 & 0.223 \\
\hline & GLA & 6.959 & 7.648 & 0.689 & 1.347 & 1.456 & 0.109 \\
\hline & Total & 6.754 & 7.630 & 0.876 & 1.259 & 1.441 & 0.182 \\
\hline \multirow[t]{6}{*}{ Humanities } & RU & 6.549 & 7.322 & 0.773 & 1.235 & 1.372 & 0.137 \\
\hline & DU & 6.695 & 7.605 & 0.910 & 1.304 & 1.433 & 0.129 \\
\hline & $\mathrm{CCU}$ & 6.630 & 7.383 & 0.753 & 1.317 & 1.475 & 0.158 \\
\hline & SLA & 7.000 & 7.640 & 0.640 & 1.298 & 1.403 & 0.105 \\
\hline & GLA & 6.880 & 7.368 & 0.488 & 1.432 & 1.429 & -0.003 \\
\hline & Total & 6.717 & 7.440 & 0.723 & 1.311 & 1.425 & 0.114 \\
\hline \multirow[t]{6}{*}{ Science \& Mathematics } & RU & 7.463 & 8.511 & 1.048 & 1.309 & 1.635 & 0.326 \\
\hline & DU & 7.642 & 8.730 & 1.088 & 1.301 & 1.517 & 0.216 \\
\hline & $\mathrm{CCU}$ & 7.539 & 8.385 & 0.846 & 1.347 & 1.598 & 0.251 \\
\hline & SLA & 8.327 & 9.440 & 1.113 & 1.403 & 1.732 & 0.329 \\
\hline & GLA & 8.006 & 8.462 & 0.456 & 1.431 & 1.515 & 0.084 \\
\hline & Total & 7.660 & 8.587 & 0.927 & 1.345 & 1.619 & 0.274 \\
\hline \multirow[t]{6}{*}{ Social Science } & RU & 6.490 & 7.530 & 1.040 & 1.251 & 1.407 & 0.156 \\
\hline & DU & 6.707 & 7.534 & 0.827 & 1.247 & 1.386 & 0.139 \\
\hline & $\mathrm{CCU}$ & 6.694 & 7.462 & 0.768 & 1.297 & 1.453 & 0.156 \\
\hline & SLA & 7.108 & 8.226 & 1.118 & 1.325 & 1.563 & 0.238 \\
\hline & GLA & 6.952 & 7.419 & 0.467 & 1.405 & 1.437 & 0.032 \\
\hline & Total & 6.725 & 7.623 & 0.898 & 1.300 & 1.452 & 0.152 \\
\hline \multirow[t]{6}{*}{ Professional/Applied } & RU & 6.190 & 7.160 & 0.970 & 1.140 & 1.294 & 0.154 \\
\hline & DU & 6.319 & 7.369 & 1.050 & 1.147 & 1.336 & 0.189 \\
\hline & $\mathrm{CCU}$ & 6.287 & 7.177 & 0.890 & 1.182 & 1.361 & 0.179 \\
\hline & SLA & 6.651 & 7.905 & 1.254 & 1.211 & 1.451 & 0.240 \\
\hline & GLA & 6.585 & 7.566 & 0.981 & 1.263 & 1.452 & 0.189 \\
\hline & Total & 6.328 & 7.252 & 0.924 & 1.182 & 1.361 & 0.179 \\
\hline
\end{tabular}

All of these analyses were repeated for samples disaggregated by the four categories of major field - humanities, science and mathematics, social science, and professional/applied fields.

To estimate the practical significance of our findings, we calculated the effect sizes by dividing the mean difference of the comparison group to the reference group by the pooled standard deviation of these two groups (Cohen 1988). Because the interpretations of the magnitude of effect size vary in the research literature we followed Cohen's guideline to treat any effect size larger than 0.2 worthy of practical consideration.

\section{Results}

Our analyses produced two major patterns of findings. First, student engagement in research-related activities increased from the mid-1990s to 2004 in all types of institutions and in all major fields. The lone exception was for students majoring in the humanities at general liberal arts colleges who reported fewer experiences working with a faculty member 
on a research project. Further analyses indicated that this was not a random fluctuation but a definite shift post 1998, inasmuch as the trend showed a slight but steady upward trend in previous years with the fairly sharp increase after 1998.

Second, research universities do not lead the pack in terms of the frequency with which undergraduates engage in research activities, relative to their counterparts attending other types of colleges and universities. In fact, the average measures of research experiences were higher in some other types of institutions such as the selective liberal arts colleges. This pattern holds both for the entire sample and for major field.

These two patterns were similar, using either the composite student research experience variable or the single-item student-faculty research variable.

Table II presents the between-time results. The sign of the effect sizes was uniformly positive across the board for the whole sample, suggesting that the frequency of undergraduate research experiences at research universities did not differ from the other types of institutions. In fact, the research experience composite was significantly higher for all other types of institutions compared to research universities in 1990-1997; in 19992004, doctoral universities and selective liberal arts colleges outpaced research universities in this regard. Students at doctoral universities and general liberal arts colleges were more likely to work with a faculty member on research in the early and mid-1990s, but this difference disappeared in 1999-2004.

The results for major field across institutional type were much more complex, making clear patterns or trends all but impossible to discern. For example, students majoring in the humanities at doctoral universities had higher scores than research universities on the two

Table II Effect Sizes of Institutional Type on Research Experience Indicators (REI)

\begin{tabular}{|c|c|c|c|c|c|}
\hline \multirow{2}{*}{$\begin{array}{l}\text { REI } \\
\text { Year }\end{array}$} & & \multicolumn{2}{|c|}{ Research Experience Composite } & \multicolumn{2}{|c|}{ Working with Faculty on Research } \\
\hline & & 1990-1997 & 1999-2004 & 1990-1997 & 1999-2004 \\
\hline \multirow[t]{4}{*}{ All } & DU & $0.127 *$ & $0.092 *$ & $0.049 *$ & 0.087 \\
\hline & $\mathrm{CCU}$ & $0.051 *$ & 0.009 & 0.030 & 0.038 \\
\hline & SLA & $0.260 *$ & $0.191 *$ & 0.024 & 0.048 \\
\hline & GLA & $0.192 *$ & 0.047 & $0.102 *$ & 0.031 \\
\hline \multirow[t]{4}{*}{ Humanities } & DU & $0.172 *$ & 0.107 & $0.147 *$ & 0.008 \\
\hline & $\mathrm{CCU}$ & $0.128^{*}$ & 0.040 & 0.081 & 0.005 \\
\hline & SLA & $0.318^{*}$ & 0.091 & 0.081 & 0.001 \\
\hline & GLA & $0.356^{*}$ & 0.113 & $0.249 *$ & 0.004 \\
\hline \multirow[t]{4}{*}{ Science \& Mathematics } & DU & 0.089 & 0.112 & -0.008 & -0.084 \\
\hline & $\mathrm{CCU}$ & 0.036 & 0.003 & 0.023 & 0.029 \\
\hline & SLA & $0.269^{*}$ & $0.246^{*}$ & -0.048 & 0.006 \\
\hline & GLA & $0.166^{*}$ & 0.029 & -0.009 & -0.040 \\
\hline \multirow[t]{4}{*}{ Social Science } & DU & $0.167 *$ & $0.117^{*}$ & 0.040 & 0.049 \\
\hline & $\mathrm{CCU}$ & $0.089 *$ & -0.028 & 0.019 & -0.019 \\
\hline & SLA & $0.335^{*}$ & $0.200 *$ & 0.094 & $0.109 *$ \\
\hline & GLA & $0.293^{*}$ & -0.094 & $0.207 *$ & -0.075 \\
\hline \multirow[t]{4}{*}{ Professional/Applied } & DU & $0.085^{*}$ & 0.087 & 0.010 & 0.057 \\
\hline & $\mathrm{CCU}$ & 0.011 & $0.186 *$ & 0.018 & $0.082 *$ \\
\hline & SLA & $0.124 *$ & 0.080 & -0.002 & 0.072 \\
\hline & GLA & $0.115^{*}$ & -0.006 & 0.069 & $0.123 *$ \\
\hline
\end{tabular}

RU was the reference group, control for other institutional and student variables

$* p<0.01$

Springer 
measures of research experiences in 1990-1997 and for social sciences on both indicators in 1990-1997 and 1999-2004. Comprehensive colleges and universities had higher average scores in the humanities and social sciences on the composite in 1990-1997 and professional/ applied fields on the composite in 1999-2004. Selective liberal arts colleges had higher average scores on humanities and professional/applied fields on composite in 1990-1997 and science and mathematics and social science fields on the composite in 1990-1997 and 19992004. While it is difficult to discern any meaningful patterns across institutional types and disciplines, what is clear is that there is no evidence of research university students being advantaged in terms of engaging in undergraduate research experiences.

Results show that undergraduates reported more experiences with research in the latter time period (Table III). This is particularly striking for the research experience composite variable, with effect sizes of around .4 for both the combined sample and different institutional types. The effect sizes for the student-faculty research activity variable were smaller-generally around 0.2 - and consistent across the analyses. The major field

Table III Effect Sizes of Time on Research Experience Indicators (REI)

\begin{tabular}{|c|c|c|c|}
\hline & REI & Research Experience Composite & Working with Faculty on Research \\
\hline \multirow[t]{6}{*}{ All } & RU & $0.405^{*}$ & $0.199 *$ \\
\hline & DU & $0.392 *$ & $0.236^{*}$ \\
\hline & $\mathrm{CCU}$ & $0.407 *$ & $0.270^{*}$ \\
\hline & SLA & $0.340^{*}$ & $0.174 *$ \\
\hline & GLA & $0.438^{*}$ & $0.256^{*}$ \\
\hline & Total & $0.397 *$ & $0.232 *$ \\
\hline \multirow[t]{6}{*}{ Humanities } & RU & $0.291 *$ & $0.130^{*}$ \\
\hline & DU & $0.382 *$ & $0.246^{*}$ \\
\hline & $\mathrm{CCU}$ & $0.295^{*}$ & $0.154 *$ \\
\hline & SLA & $0.186^{*}$ & 0.067 \\
\hline & GLA & $0.247 *$ & -0.053 \\
\hline & Total & $0.255^{*}$ & $0.093 *$ \\
\hline \multirow[t]{6}{*}{ Science \& Mathematics } & RU & $0.340 *$ & $0.158^{*}$ \\
\hline & DU & $0.348^{*}$ & 0.135 \\
\hline & $\mathrm{CCU}$ & $0.315^{*}$ & $0.240^{*}$ \\
\hline & SLA & $0.232 *$ & 0.119 \\
\hline & GLA & $0.386^{*}$ & $0.283^{*}$ \\
\hline & Total & $0.332 *$ & $0.198^{*}$ \\
\hline \multirow[t]{6}{*}{ Social Science } & RU & $0.455^{*}$ & $0.188^{*}$ \\
\hline & DU & $0.353^{*}$ & $0.213^{*}$ \\
\hline & $\mathrm{CCU}$ & $0.327^{*}$ & $0.207 *$ \\
\hline & SLA & $0.491 *$ & $0.279 *$ \\
\hline & GLA & $0.349^{*}$ & 0.138 \\
\hline & Total & $0.379 *$ & $0.194 *$ \\
\hline \multirow[t]{6}{*}{ Professional/Applied } & RU & $0.525^{*}$ & $0.270^{*}$ \\
\hline & DU & $0.512 *$ & $0.371 *$ \\
\hline & $\mathrm{CCU}$ & $0.471^{*}$ & $0.306^{*}$ \\
\hline & SLA & $0.620^{*}$ & $0.272 *$ \\
\hline & GLA & $0.532 *$ & $0.371 *$ \\
\hline & Total & $0.493 *$ & $0.303 *$ \\
\hline
\end{tabular}

1990-1997 as the reference group, control for other institutional and student variables $* p<0.01$ 
analyses revealed the same overall pattern of increased activity, except for the studentfaculty research item for humanities majors at selective liberal arts colleges and general liberal arts colleges, science and math majors at doctoral universities and selective liberal arts colleges, and social science majors at general liberal arts colleges.

In light of the overall pattern of increased frequency of participating in researchrelated activities, we attempted to determine the amount of change over time by institutional type. The results in Table III suggest that the magnitude was more or less consistent across type of school. The one exception was humanities students at general liberal arts colleges who reported fewer experiences working with a faculty member on a research project.

\section{Discussion}

The results of this study indicate that more undergraduates participated in research-related activities since 1999 compared with the preceding five year period. This increase was not limited to research universities but occurred across all institutional types. In fact, students at research universities do not participate in such activities as often as their peers at liberal arts colleges and doctoral universities. Thus, although research universities perform an array of basic and applied research in virtually every field unlike that of any other educational institution (Geiger 1993; Graham and Diamond 1997; Lipset 1994; Rosovsky 1990), there does not appear to be any advantage to undergraduates attending a research university in terms of doing research with a faculty member. Perhaps this is because undergraduates do not compare favorably against graduate students who have more knowledge and research experience and skills to bring to collaborations on research. In contrast, faculty members at liberal arts colleges and other institutions focused primarily on undergraduate education have few to turn to other than undergraduate research assistants to build a research team (Zimmer 2005).

Institutional size may also influence the number of undergraduates participating in research activities. Research universities tend to be large and have student-faculty ratios that limit the number of students with whom faculty members can work. While many institutions attempt to compensate for size and induce faculty to include undergraduates in their research programs, the amounts available to support such efforts may be insufficient to boost participation to the desired levels. Another reason might be the range and nature of research programs available to the students. Even though a lot of exemplary programs of undergraduate research opportunities are advertised and featured by institutions, they may not be widely available for the average undergraduate student population since participation in these programs is often quite competitive. As Merkel (2003) suggested in her overview of undergraduate research at the research universities, "it is still the top students who get to do research" (p. 39).

On balance, the results of this study indicate that the calls for improving undergraduate education by encouraging students to work with faculty on research activities may be having the intended effects. For example, the Association of American Colleges and Universities (2007) recently pointed to student-faculty research as an effective educational practice. The good news is that across the board, more students had such experiences after 2000 than in the years immediately preceding the Boyer Report of 1998. This trend is consistent with Katkin's (2003) assessment on the impact of the Boyer Report. Even though the report was primarily critical of research universities, it may have had a salutary effect on other types of colleges and universities, urging them to use research experiences to improve undergraduate education. To some extent, this is an illustration of institutional isomorphism 
(Altbach 1998; Kuh and Hu 2001; Riesman 1958) in that research universities are thought to set the tone for the entire system (Altbach 1998).

Also contributing to the increase in undergraduate student participation in research with faculty members is the fact that this activity has been widely proclaimed as highly desirable by various national organizations. For example, in its Greater Expectations report, the Association of American Colleges and Universities (2002) encouraged institutions to provide more hands on inquiry-related experiences to empower students as learners. Equally important, recent research has underscored the value of having a research experience as an undergraduate. In this regard, the widely used National Survey of Student Engagement (2005) includes student-faculty research on its enriching educational experience benchmark of effective educational practice. With so many groups endorsing the practice, it is not surprising that the number of students involved has increased.

As with other effective educational practices, such as service learning or first-year seminars, just because a student has the experience does not necessarily mean that it will enrich learning or be developmentally powerful. In terms of doing research with a faculty member, the impact of the experience surely must depend on the quality of the relationship between student and faculty member, the length and nature of the research project, the role of the student, and the nature and frequency of feedback the student receives during the endeavor. Thus, there is much more to learn about the effects of student-faculty research and the characteristics of such collaborative efforts that make for a productive, rewarding activity for both partners.

\section{Limitations}

This study is limited in several ways. First, the data are from a convenience sample of institutions that elected to administer the CSEQ. Perhaps some of these schools use the instrument because they are more interested in the quality of the undergraduate experience than some other institutions. Also, different schools participate in different years. The changes may be influenced by the fact that different schools participated at different times, even though we controlled for many student and institutional characteristics in the study. Finally, the results might change if different questions were asked about the nature of the research experience, such as whether or not the research activity was done for credit, as part of a course, or if the student was in a special program such as McNair Scholars, or otherwise compensated for the work. Even with these limitations in mind, the major finding that more students are participating in research-related activities would not likely change, though the magnitude of the effect might differ somewhat.

\section{Conclusion}

Since the release of the Boyer Report in 1998, the number of undergraduates reporting research experiences has increased at all types of college and universities. This fact suggests that reforms in undergraduate education are possible when many different parties concentrate on specific areas to improve. While student engagement in research activities at research universities has also increased in recent years, undergraduate students in those institutions do not enjoy a relative advantage compared with their peers at other institutions. If research universities wish to provide enriching educational opportunities consistent with their distinctive research mission, they need to create more inquiry-oriented educational opportunities for their students. 


\section{References}

Altbach, P. G. (1998). Comparative higher education: Knowledge, the university, and development. Greenwich, CT: Ablex.

Association of American Colleges and Universities (2002). Greater expectations: A new vision for learning as a nation goes to college. Washington, DC: Association of American Colleges and Universities.

Association of American Colleges and Universities (2007). College learning for the new global century. Washington, DC: Association of American Colleges and Universities.

Barron's Profiles of American Colleges (2002). Hauppage, NY: Barron's Educational Series.

Boyer Commission on Educating Undergraduates in the Research University. (1998). Reinventing undergraduate education: A blueprint for America's research universities. Stony Brook, NY: The Carnegie Foundation for the Advancement of Teaching.

Carnegie Foundation for the Advancement of Teaching. (1994). A classification of institutions of higher education. Princeton, NJ: Carnegie Foundation for the Advancement of Teaching.

Clark, B. R. (1983). The higher education system: Academic organization in cross-national perspective. Berkeley, CA: The University of California Press.

Cohen, J. (1988). Statistical power analysis for the behavioral sciences (2nd ed.). Hillsdale, NJ: Erlbaum.

Council on Undergraduate Research. (2003). Faculty-undergraduate collaborative research and publishing. Retrieved September 5, 2005, from http://www.cur.org/wp_respub.html

Duke University (2006). Duke University bulletin of undergraduate instruction 2006-07: Degree programs. Retrieved March 21, 2007, from http:/www.registrar.duke.edu/bulletins/Undergraduate/2006-07/degrees.pdf

Ethington, C. A., Thomas, S. L., \& Pike, G. R. (2002). Back to the basics: Regression as it should be. In J. C. Smart (Ed.), Higher education: Handbook of theory and research, vol. 17 (pp. 263-293). Dordrecht, The Netherlands: Kluwer.

Ewell, P. T., \& Jones, D. P. (1996). Indicators of "good practice” in undergraduate education: A handbook for development and implementation. Boulder, CO: National Center for Higher Education Management Systems.

Geiger, R. L. (1993). Research and relevant knowledge: American research universities since World War II. Oxford, England: Oxford University Press.

Gonyea, R. M., Kish, K. A., Kuh, G. D., Muthiah, R. N., \& Thomas, A. D. (2003). College Student Experiences Questionnaire: Norms for the fourth edition. Bloomington, IN: Indiana University Center for Postsecondary Research and Planning.

Gonzalez, C. (2001). Undergraduate research, graduate mentoring, and the university's mission. Science, 293, $1624-1626$.

Graham, H. D., \& Diamond, N. (1997). The rise of American research universities: Elites and challengers in the postwar era. Baltimore, MD: The Johns Hopkins University Press.

Hathaway, R. S., Nagda, B. A., \& Gregerman S. R. (2002). The relationship of undergraduate research participation to graduate and professional education pursuit: An empirical study. Journal of College Student Development, 43, 614-631.

Justice, C., Rice, J., Warry, W., Inglis, S., Miller, S., \& Sammon, S. (2007). Inquiry in higher education: Reflections and directions on course design and teaching methods. Innovative Higher Education, 31, 201-214.

Katkin, W. (2003). The Boyer Commission Report and its impact on undergraduate research. In J. Kinkead (Ed.), Valuing and supporting undergraduate research (pp. 19-38). San Francisco, CA: Jossey-Bass.

Kuh, G. D., \& Hu, S. (2001). Learning productivity at research universities. Journal of Higher Education, $72,1-28$.

Kuh, G. D., Kinzie, J., Cruce, T., Shoup, R., \& Gonyea, R. M. (2006). Connecting the dots: Multi-faceted analyses of the relationships between student engagement results from the NSSE, and the institutional practices and conditions that foster student success. Bloomington, IN: Indiana University Center for Postsecondary Research.

Kuh, G. D., Vesper, N., Connolly, M. R., \& Pace, C. R. (1997). College student experiences questionnaire: Revised norms for the third edition. Bloomington, IN: Center for Postsecondary Research and Planning, School of Education, Indiana University.

Lipset, S. M. (1994). In defense of the research university. In J. R. Cole, E. G. Barber, \& S. R. Graubard (Eds.), The research university in a time of discontent (pp. 219-224). Baltimore, MD: The Johns Hopkins University Press.

McCormick, A. C. (2000). The 2000 Carnegie classification: Background and description. Retrieved on April 5, 2005, from http://www.carnegiefoundation.org/Classification/CIHE2000/background.htm

Merkel, C. A. (2003). Undergraduate research at the research universities. In J. Kinkead (Ed.), Valuing and supporting undergraduate research (pp. 39-53). San Francisco, CA: Jossey-Bass. 
Nagda, B. A., Gregerman, S. R., Jonides, J., Hippel, W., \& Lerner, J. S. (1998). Undergraduate studentfaculty research partnerships affect student retention. Review of Higher Education, 22, 55-72.

National Commission on the Future of Higher Education. (2006). A test of leadership: Charting the future of U.S. higher education. Washington, DC: U.S. Department of Education.

National Survey of Student Engagement. (2005). Student engagement: Exploring different dimensions of student engagement. Bloomington, IN: Indiana University Center for Postsecondary Research.

Nnadozie, E., Ishiyama, J., \& Chon, J. (2001). Undergraduate research internships and graduate school success. Journal of College Student Development, 42, 145-156.

Pascarella, E. T., \& Terenzini, P. T. (2005). How college affects students: A third decade of research. San Francisco, CA: Jossey-Bass.

Riesman, D. (1958). The academic profession. In D. Riesman (ed.), Constraint and variety in American education (pp. 25-65). Garden City, NY: Anchor Books.

Rosovsky, H. (1990). The university: An owner's manual. New York, NY: Norton.

Volkwein, J. F., \& Carbone, D. A. (1994). The impact of departmental research and teaching climates on undergraduate growth and satisfaction. Journal of Higher Education, 65, 147-159.

Zimmer, M. (2005, August 12). How to find students' inner geek. Chronicle of Higher Education, B5. 